\title{
A Comparison of the Economic Situation of Tyrol, Austria in Three Key Periods: 1908-1913, 1945-1950 and 2008-2013
}

\author{
Dirk-Hinnerk Fischer \\ Tallinn School of Economics \\ and Business Administration, \\ Tallinn University of Technology \\ Akadeemia tee 3, \\ Tallinn 12618, Estonia \\ E-mail: Dirk-Hinnerk.Fischer@ttu.ee
}

Abstract: The development of a formerly poor state in a great European power to a rich state in a small European country is remarkable. But the interest of this article is mainly on the methodology which is based on the exclusive focus on three key periods in the history of the observed region. This methodology leads to a very specific understanding of development and economic growth. The periods chosen in this example are the five years before the First World War, as it was a period of development and growth that in the end led to the fundamental crisis in the 20th century. The second period consists of five years following the Second World War. This period was crucial, as many fundamental developments were laid in this time. The final period begins with another big economic crisis in 2008. The selection is based on three rationales. First, it allows a comparison of how the population deals with crisis. Second, it provides a cross-section of over hundred years, and third, the topicality of these years increase the relevance of the paper.

Keywords: development, economic history, periodic approach, Tyrol

\section{Introduction}

The primary aim of this paper and the choice of the time periods was to bridge a period of over a hundred years. The research enabled a direct juxtaposition of the first and the last period given here. Both were times of economic change, but 
unlike the second period, not times of absolute crisis. Wishing to avoid threading on thin ice with this claim calls for further explanation. The crisis of 2008 was critical but, unlike the crisis of 1929, it was only an economic crisis, which did not destroy the system or brought about major changes; however, this is not a topic of this paper. While the object of study was originally designed to be of international scope, the author soon realised that there are no comparative approaches on the topic and, thus far, such comparison is not possible and will remain for further research. Also, the title of this article has a sense of absoluteness about it, and, to be fair, the article cannot fulfil these expectations. To keep the article's orientation objective, the author had to pick some crucial markets, traditional markets and important tendencies within Tyrolean economy and society.

Even though the article focuses on the analysis of social and economic developments of Tyrol during the past one hundred years, it is related to the Baltic countries and European integration for the following reason: the methodology can be easily adapted from the Austrian federal state to any smaller European country, such as the Baltic countries, and it is also adaptable to any other federal state in the EU. Also, whether a country was part of the former Soviet Union, a dictatorship or similar, is not relevant. The paper will give a unique and alternative insight by contributing to understanding Tyrol's development during the past one hundred years.

Another reason for this publication is the great influence that the European integration process has had on Tyrol, not only economically but socially and politically as well. In this sense, it is not only similar to the Baltic region, but to most parts of modern Europe. The only difference is how people deal with it.

Yet another similarity and possibility for adaptation of some of the methodologies used in this paper is that Tyrol, like Lithuania, has had its borders changed during the last one hundred years. This has not only had a political but also a social impact on the population of the whole region.

The data analysed in the paper is not limited strictly to the given periods. Each period is closed in one direction but left open in the other. The reason for that is logical, because sometimes it is just not possible to obtain data within the given period. But it is also crucial that the data would not get mixed with the data from periods of war or other extreme times, as this data usually shows different tendencies than that of peaceful years. The end date of the third period is closed for the investigation as it limited with present day. This, however, does not mean that the article has neither ability nor willingness to demonstrate tendencies falling between the periods. 


\section{Short theoretical framework}

As mentioned in the introduction, the research was originally planned to be slightly different but turned out quite successful, as it could only get this focused within the following predetermined criteria:

1. The study focuses only on Tyrol and provides no comparative material on other Austrian federal states or regions of other countries.

2. The chosen periods have to be adapted to the history of the analysed region, country or county. In the case of Estonia, the corresponding periods could be the five years after 1934, the five years preceding the restoration of independence in 1992, and the last five years following the first big economic crisis as a free nation.

- The first period. Assumption: This is the most difficult period to research. Data available on this period was probably also available in the other periods. It was actually true 95 per cent of the time. Research of this period requires particular flexibility, which means that not only data from 1908 to 1913, but also from 1914, that is, wartime data, was not acceptable.

- The second period. Assumption: The data would get better with each year following the war. This assumption was entirely true, so the focus was shifted on the latter years within the period. The data became really reliable from 1948 on. The documentation of the period began with the election of the first Tyrolean provisional government in May 1945, although generalised data from 1945 was not allowed, as this data was still very much influenced by the war.

- The third period. Assumption: If data is not available it is because of political interest and not because it did not exist. Also, this assumption has proven to be true.

3. The markets, social aspects or political results have to be chosen carefully, as the comparison might be difficult because of the shifting of the focus of interest in time.

4. The focus is on humans. Data that includes human factor is more easily comparable and easier to understand than a number of goods or monetary values.

5. Average values across the periods have to be used to avoid emphasising tendencies, if a data on a particular year is used, and to maintain objectivity of the work. 
The research was also influenced by the changing borders. The author decided to calculate average values, based either on population density or on the economic capacity of each region whenever specific data was not available.

\section{Development and results}

The federal state of Tyrol as part of modern Austria includes Nordtirol, with its capital Innsbruck, and Osttirol with Lienz as its district capital. The other parts shown on the map now belong to Italy, but were not during the first period (see Fig. 1). All data mentioned hereafter will be calculated only for the borders of the federal states, if not stated otherwise. Adapting the methodology to important periods of an area, region or country is not difficult.

Figure 1. Map of Tyrol (Tirol Geschichte, 2013)

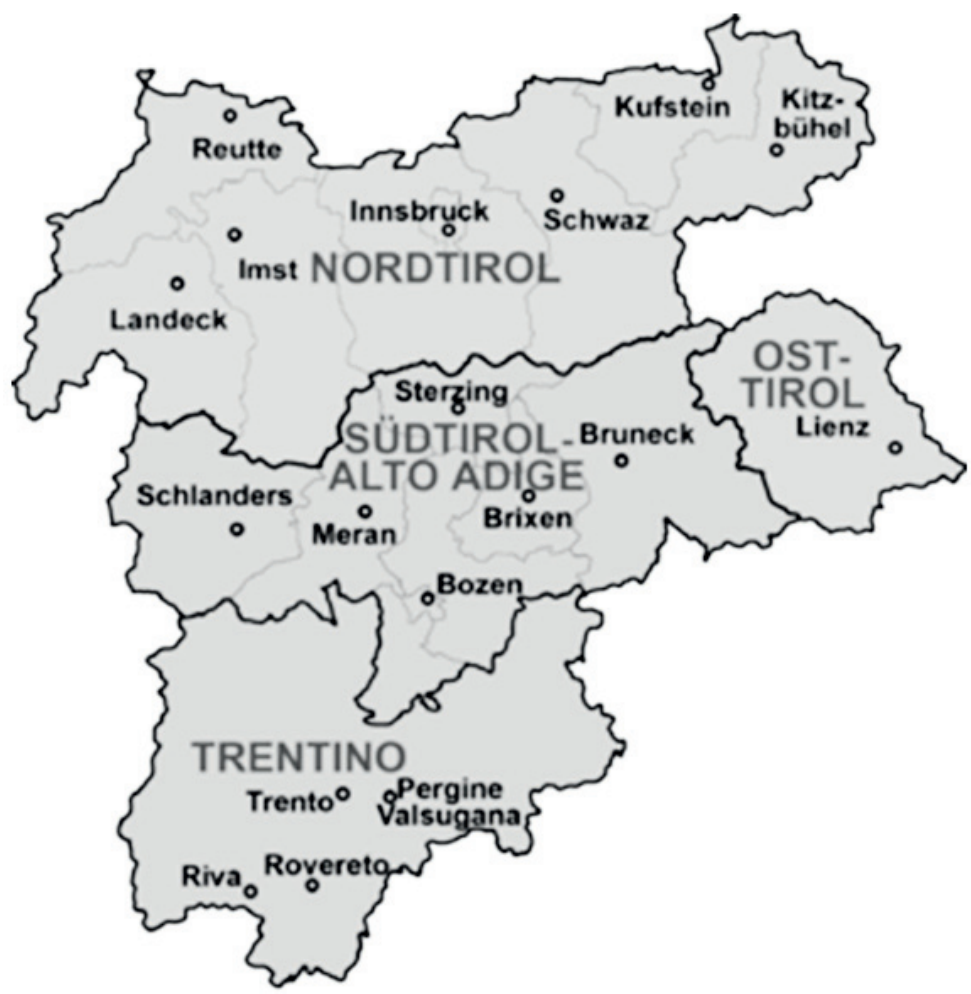

This kind of research often falls prey to a type of old nostalgic argument that "everything was better in those days" or "the good old days", but the research 
shows the exact opposite. The first period is sometimes idealised as a beautiful time. This is only true for selected parts of the society and even for them the constant threat of the upcoming war must have been very disturbing. Additionally, Austrian-Hungarian preparations for war to gain back the lost power over the Balkan were disturbing the peace and freedom of the population (Fontana et al., 1987, pp. 407ff). An interesting fact after showing the results of the paper to some Tyroleans is that the fear of losing the national or regional identity was minimised. This fear is still present in Tyrol and the data has shown how such aspects, which the population today sees as important, got lost at the time.

The first result of this paper has been shown in numerous other papers as well. The research revealed that the sources often fail to show resounding results, and in our days only display the interest of a particular peer group. This is true for all three periods. In each period there appeared a clear difference in the interests of various lobbying organisations, which is why a non-neutral researcher would have had quite different outcomes. This was the point that determined the direction of the author's recent research on lobbying and market reaction on interventions.

A very important, although also obvious result is that Tyrol endured a harsh structural change during this century. It developed from a poor agricultural region, within the Kaiser und König Monarchie ('Imperial and royal monarchy', as the Austrian-Hungarian empire was called internally, below referred to as $\mathrm{K} \& \mathrm{~K}$ ) to a highly technologised and tourism-oriented federal state. This change was necessary, because Tyrol, as an alpine region, had not been capable of providing for its habitants since the Middle Ages and has depended on imports ever since. (Kölner \& Rohn, 1910, p. 37) This situation escalated dramatically due to the fast growth in population during the periods and even today Tyrol has by no means the capability to feed its population. This is accompanied by dramatic changes in employment statistics. The last period shows almost a perfectly mirrored image of the structure of the first period. The average density of the population across the whole state in the first period was 24.62 inhabitants per square kilometre and 311,209 in total. By the second period it was already 34.43 and 427,300 in total. In the most recent period it was 56.17 inhabitants per square kilometre and on average 707,485 people who resided in Tyrol. (Arbeiterkammer für Tirol, 1958, pp. 26ff; Landesstatistik Tirol, 2013, p. 3) These figures are important in terms of population growth. Regarding the density of the actual state, one would have to eliminate all the uninhabitable areas from the equation, but that leads into too much detail in this short summary. 
A first surprise was that the percentage of the population with an immigration background from the second to the third period did not change noticeably (11.6\% in $1948 ; 11.8 \%$ in 2012), especially if one takes into account that the K\&K monarchy was multiethnic. Thus, a part of the population who were called foreigners in the second and third period had been subjects of the Austrian empire in the first period (1.5\% in 1910) (Landesregierung, 1910; Landesstatistik Tirol, 2013, p. 3).

The mentioned growing diversity could be noticed also in religion (Table 1). In the first period, 98 per cent of the population were Roman Catholics.

Table 1: Religious affiliation of the people of Tyrol in 1910, 1951 and 2001.

\begin{tabular}{|l|r|r|r|r|r|r|r|}
\hline & $\begin{array}{l}\text { Roman } \\
\text { Catholics }\end{array}$ & $\begin{array}{l}\text { Protes- } \\
\text { tants }\end{array}$ & Jews & Muslims & Other & $\begin{array}{l}\text { No } \\
\text { religious } \\
\text { affiliation }\end{array}$ & $\begin{array}{l}\text { Total } \\
\text { population }\end{array}$ \\
\hline *1910 & 938,362 & 6,007 & 1,624 & N/A & 627 & N/A & 947,000 \\
\hline $\begin{array}{l}\% \text { of the } \\
\text { total popu- } \\
\text { lation }\end{array}$ & 99.09 & 0.65 & 0.19 & N/A & 0.07 & N/A & 100 \\
\hline $\begin{array}{l}1951 \\
\% \text { of the } \\
\text { total popu- } \\
\text { lation }\end{array}$ & 904,762 & 12,835 & 50 & N/A & 1,609 & 8,025 & 427,465 \\
\hline $\begin{array}{l}2001 \\
\text { \%a of the } \\
\text { total popu- } \\
\text { lation }\end{array}$ & 84.75 & 3.02 & 0 & N/A & 0.04 & 1.88 & 100 \\
\hline
\end{tabular}

* The figures apply to the area within Tyrolean borders of that time (including Southern Tyrol and Trentino) (Stolz, 1955, pp. 335, 688ff; Statistik Austria, 2013a)

Other reasons for the growth of the population are definitely the drastically reduced infant mortality, which dropped from over 21 per cent in 1905 to 5.6 per cent in 1948, and 0.39 per cent in 2010. The growth of life expectancy also helped to increase the population. This is logical as it rose for men from around 42 years in the first period to almost 80 in the third. The same applies to statistics about women, whose life expectancy increased from around 45 to 83 . In the period after the Second World War the corresponding figures were 61 for men and 64 for women (Statistik Austria, 2013d).

To summarise shortly, the most important influential factors for these positive results are the dramatically improved medical coverage and education, as well as the clearly improved food security. The first mentioned factor characterises 
the second period as exceptional. It was a time of true crisis and a setback in development and the quality of life. To emphasise this fact, one only has to look at the food supply in the different periods. There are no reports of people dying from hunger or thirst in the first period. Most of the population was well-fed, even though there was great poverty and major social problems, such as, for example, many alpine farmers with small property having had to send their children away. These Schwabenkinder where brought to Germany to work there as shepherds or at other agricultural jobs instead of attending school or working on their own land, but there is no documentation at all that someone died from hunger during this period.

In the second period, the occupying power set up daily limits for calorie supply for each person. Between 29 May 1945 and 23 June 1945, the daily amount of calories available per adult was 800 . The amount increased in each period, but according to many reports sometimes only half of this amount was actually provided. In the last period, from 13 October 1947 to 11 November 1947, the calorie supply was supposed to be 1,360 , but the actual amount still differed from region to region (Nussbaumer, 1984, p. 141).

In the third period, every fifth child in Tyrol was overweight (Bezirksblätter, 2013). Here it has to be emphasised that Tyrol still has the same pension scheme as in the second period. The question is whether it can be sustainable in the future.

Another structural change took place during the periods. The majority of the Tyrolean population is no longer dwelling in "three generation houses", but live alone or as a pair. Due to these changes, urbanisation and the number of houses almost quadrupled from the first to the third period. The process developed as follows: The total number of 44,898 houses in 1910 increased only to 55,725 in 1951 and to 166,910 in 2010 . The number of flats increased even more drastically from 61,000 to 113,650 to 343,931 , respectively. (Nussbaumer \& Neuner, 2012, pp. 177ff; K.K. Statistische Zentral-Kommission, 1911)

As one of the central interests for the population, the article also discusses education. The rate of illiterate population sunk from 21 per cent in the year 1900 to a little under 5 per cent in the third period (Tiroler Tageszeitung, 2013; Österreichischer Zentralkataster, 1908, p. xii). Meanwhile the number of students and graduates within the population increased to a level at which it becomes questionable whether the number is actually necessary for a region like Tyrol. The percentage of students in the total population increased from period to period - first it was 0.38 per cent, then 0.83 per cent, and by today has risen to 3.97 per cent. The percentage points of the development of graduates in the total 
population increased accordingly (Amt der Landesregierung, 2013; Kargnugn, 1950; Dokumente..., 1909).

The importance of integration and international partnering is indicated by a formerly important measure-namely, the number of soldiers stationed within the borders of Tyrol. The number sunk rapidly due to the formation of partnerships. In the most recent period, 1,500 Austrian soldiers were stationed in Tyrol. In the second period, there were around 20,000 French soldiers, and in the first period around 3,700 Austro-Hungarian soldiers stationed within the modern borders of Tyrol.

However, the focus of this article is economic development, growth and stability. One measure for economic growth is the number of cars per capita. In this study the number has grown from 0,0007 per cent in 1910 to 0,00281 per cent in 1948, and 50 per cent in 2011. (Österreichische Gesellschaft Statistiches Handbuch, 2013; K.K. Statistische, 1908)

An important indicator of the economic future is the number of patents issued in a country or a region. This indicator shows a positive tendency, as in 1910 there were 15 applications and 6 patents issued. This number was almost zero in the last year of the war and grew exponentially from then on in the following years. By 1950, everyday life had returned more or less to normal and thus the number of applications was 210 , of which only 68 were granted. In 2010, the number of submitted applications was 231 and 135 patents were given. (Statistische Übersicht..., 2013; Alexander, 2007, pp. 18ff; Österreichisches Patentblatt, 1912)

An economically and socially gaining trend in tourism can be reported. While in the first period, summer was the only high-season in tourism and winter sports just started to become popular, today, winter is by far a more important market. After the Second World War, allied troops were concerned about the still existing German influence on Austria. So they banned all German travels for years. As Germans always were and still are the most important group of tourists in Tyrol, the impact of this policy is clearly visible. After the ban was lifted in 1948, the number of visitors increased drastically and helped Tyrol return to stabilised development processes.

The analysis of the countries of origin of the visiting tourists shows that tourism in the region has opened itself, due to European integration, to more countries, but Tyrol would still benefit from a greater diversification of tourists to protect the country from any kind of crisis. Since tourism is by far the most important market in Tyrol, this aspect is one of the most important measures for 
the sustainability of Tyrol's growth. Additionally, under the impact of climate change, the Alps and its countries have to adapt to winters with little snow and hot summers. This is one of the big challenges for Tyrol's future.

Another important factor, one that does not depend on weather, is the role of a logistics provider that Tyrol has in the middle of Europe's infrastructural system. As there are only a few well established north-south connections through the Alps, Tyrol holds a quasi-monopoly within this market. A problematic factor is once again the dependency on the German market, but luckily by far not all goods are for or from the German market. The Brenner Pass, one of the most important routes through the Alps, has developed over the three periods from a small alpine trail to a small road and a small train track, then to a pass street, an alternative motorway, or Autobahn, and a highly effective railroad. And still various governments are working together to finish one of the biggest tunnel projects in the history - the construction of the Brenner Base Tunnel, which started on 20 August 2007. This project will allow once again an enormous increase in traffic and additionally it will shorten the travel time needed pass the Brenner. (BMVIT, 2011, pp. 37-59, 140ff) The project is also a symbol of international integration, as three governments are actively participating in the construction and the tunnel will help to speed up the liberty of movement.

An interesting point from the economic aspect is that the unemployment rate actually rose. At closer observation it is logical, as in the past women did not hold jobs, looked after household and children and helped on the fields. So women did not apply for state unemployment benefits, and also the number of men who did, that is, those who had not inherited any land, was very small. The population's working conditions have improved dramatically. Nowadays, every employee in Austria should receive salary 14 times a year. The working hours are regulated and the termination of the contract is very favourable towards employees, even so that smaller companies actually have to think about hiring new staff, as dismissing someone in times of crisis might hurt the entire company.

In some cases, the results of the established criteria could be predicted already before the research even started. One of these was the number of Tyrol's inhabitants. Other very predictable results were the analyses of the inflation rate, the cost of living, average wages, the cumulated length of roads, streets, and also various percentage estimates, such as kilometres of streets per inhabitants or increase in traffic over the Brenner Pass across the periods. The research also revealed some diverse results, such as, for example, the surprisingly quite opposite course of development of textile and chemical 
industries. This development is best shown by the number of employees. In 1910, the textile industry, at that time one of the most important industries in Tyrol, employed 1,184 people. The number increased to 2,587 in 1948 and dropped, due to labour costs, to 590 in 2009. The development of the chemical industry, on the other hand, employed 120 people in 1910 and 300 in 1948. This number grew, due to the specialisation in Tyrol to 5,666 employees in 2009. (Bureau der K.K..., 1910, pp. 46ff; Günther, 1951, p. 288; Amt der Landesregierung, 2013) Interestingly enough, the general structure of Tyrol's economy remained unchanged. The third period led to a slight decrease in the percentage of companies, of which 89 per cent used to be small-sized companies (with less than nine employees). There are only a few exceptions, such as Swarovski or Egger. Regardless of its economic structure, Tyrol's economy is highly competitive.

One general aspect is still missing from this list-politics. To begin with a negative example of development, the research showed a decrease in electoral participation rates and awareness of democratic possibilities (data not available for the first period, $96.57 \%$ in 1948, and $60.1 \%$ in 2013) (Rauchenberger \& Fasching, 2000, pp. 418-441; Amt der Landesregierung, 2013). This decrease gives extremist parties a possibility to gain influence and destabilise the system. Further research will show whether the political apathy is encouraged by the endogenous formation of opinions by some powerful mass media companies or whether it actually is encouraged by the consistency of the Tyrolean politics.

In the first period, the parliament consisted of four parties (Fig. 2). At the 1945 elections, due to the exclusion of persons associated with the national-socialist system, there were only two parties in the parliament. At the next elections in 1949, the system changed to three parties, when the VdU (Federation of Independents, today's FPÖ, or Freedom Party of Austria) was established and gathered most of the votes from the formerly excluded Tyroleans (Achrainer \& Hofinger, 1999, pp. 40, 49). After the 2013 elections, there are six parties in the parliament.

The graph from 1908 requires some explanation. The results of this year show the win of the Christian Socialists' Party (chr. Soz), which was united with the Conservative Party (Kons.) after the First World War, and today is the Austrian People's Party, or ÖVP. Then there is a German Freedom Party (D. freiheitl.) and the national liberal party of Italy (National lib. Ita.). These two parties were SouthTyrolean organisations with clearly oppositional interests, since one wanted South Tyrol to be a part of Austria and the other wanted it to become a part of Italy. In these days, there were even violent confrontations between these parties. 
Figure 2. Distribution of votes among political parties in 1908, 1949 and 2013. *

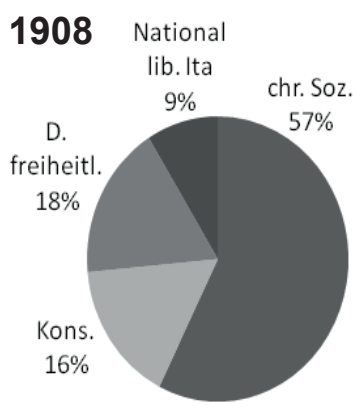

1949

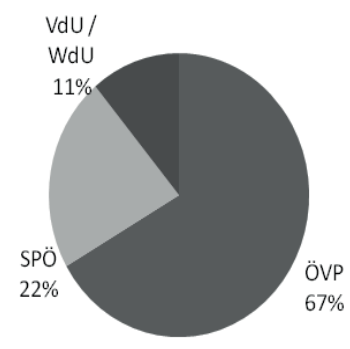

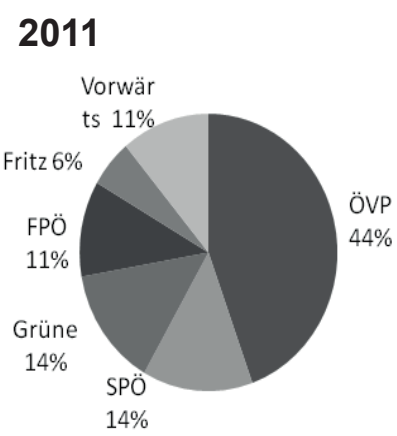

* Estimated values (Achrainer \& Hofinger, 1999, p. 106; DVT, 2013).

The other parties are: SPÖ (Socialist Party), nationalist liberal VdU/ FPÖ, Grün ('The Greens' or environmental party, Fritz (a small party dealing mostly with regional topics in Tyrol, formed by a former member of the ÖVP, and the liberal modernist Vorwärts ('Forward Tyrol'). As the beginnings of the VdU were controversial, so is also the FPÖ. At the elections of the city council of Innsbruck, the capital and by far the largest city in Tyrol, the party started their campaign with the slogan: "Heimatliebe statt Marokkanerdiebe" (the verbatim translation of the rhyme is: Love of our nation instead of thieves from Morocco) (Der Standart, 2012). In the Nationalrat, or National Council of the Austrian Parliament, the FPÖ has 20.51 per cent of the seats. (BMI, 2013)

The most important political changes in each period are probably the Sanitätsgesetz in 1908, which ensured for the first time in Tyrol's history a decent medical care. The Landesschulgesetz a year later made further education possible for Tyroleans. In the second period, no doubt, the most important change was the reinstating of democracy. In an interview with an anonymous Tyrolean bureaucratic official, I asked which jurisdictive, legislative or other political achievement of the third period could have had decisive impact on the life of the future inhabitants of Tyrol. The short and unhesitant answer was: "None." Of couse this is a subjective opinion, but I asked the official not only out of curiosity but because my research on this matter had not given any results.

One of the most surprising aspects was the continuous tendency in the average marrying age. The average age did not change as much as expected, but just changed from 29.4 years in the first period to 29.2 years in the last period. The average age in the postwar period peaked to 31.4 years in 1945 (Bundespressedienst, 1947; Statistik Austria, 2013c). 
A fact almost as surprising as this was that the districts of Tyrol grew proportionally, and it was not expected that Innsbruck would grow much faster than all the other districts. As everyone can see there are only slight changes, mainly in comparison with the second period. Many expatriated and uprooted people were still not back on their feet and were living in temporary dwellings. Overall, hardly any changes can be seen between 1910 and 2011 (Fig. 3).

Figure 3. Urban populations by Tyrolean regions in 1910, 1948 and 2011, \%

\section{0}

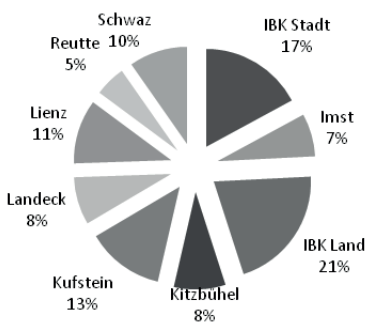

1948

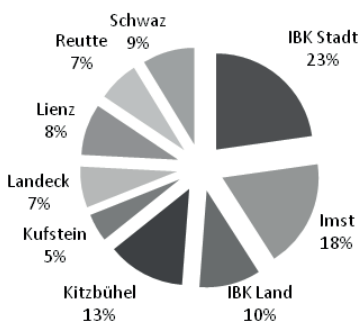

2011

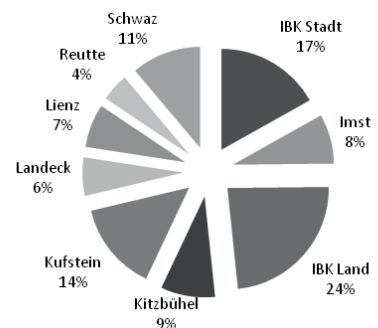

Source: Amt der Tiroler Landesregierung, 1948, p. 55; City Population, 2013; K.K. Statistische Zentral-Komission, 1911, pp. IXff, XVI, 9.

Tyrol could always depend on its availability of fresh water. This fact ensured food security, as even though Tyrol could not fully provide for its own population, its water kept the population alive. Nowadays Tyrol uses its water not only for nutrition but it gives Tyrol also the opportunity to be independent in energy matters and use highly advanced research and investigation technology in various energy-related issues.

\section{Conclusion}

Austria joined the European Union in 1995 and by doing that gave up its fundamental basis of neutrality. To this day there is still a considerable group of citizens that would prefer Austria to regain its former neutral role. This is only one of many examples how the past of this beautiful but very conservative country is idealised, but every country, every region has its past and is trying to deal with it. Within the framework of the three key periods chosen here, the kind of historical-economic period analysis used in this article has proved very useful in explaining recent developments. The methodology also emphasises in this case how the Tyrolean people have dealt and continue to deal with crises and also shows the fundamental basis that had to be built in economy, 
politics and infrastructure to achieve the high standard of living that Tyrol boasts today.

What does the article really say about Tyrol? The comparison of these very distinct three periods falling within a hundred years clearly states that the people involved differed in their knowledge and level of technological advancement. But it is to say that apart from that they reacted similarly and followed continuous patterns, which are usually called traditional behaviour. Each period demonstrated specific challenges. The study gives an idea of what can happen if these challenges are not responded to. In the first period, politicians had to confront fundamental social challenges. The second period was obviously dominated by the reconstruction and establishing the democratic process and laying foundation for the economy. In the third period, the population has had to learn how to live in an increasingly rapidly changing environment.

The expected growth of Tyrol's GDP leaves almost nothing to question, except for, perhaps, whether the growth is really sustainable or is it about to be diminished by crisis and instability. Additionally, one may wonder as to which extent does the growth reflect real additional value, but this is more a philosophical question.

The main results regarding the Tyrolean society are that it became more diversified and open-minded. The paper also shows a clear continuance in the behaviour of Tyrol's population. This means that while we might know what happened after the boom phases at the beginning of the last century, and also about what happened after the defeat of the Third Reich, we do cannot predict future after the third period.

If the economic basis (i.e. income, wealth, income gap, wealth gap, subjective encounter of the economic situation, etc.) is carefully monitored, there is nothing that could prevent Tyrol having a positive future. The article, in general, shows that people in Tyrol still have the same fears, wishes and desires than they had a hundred years ago. Due to the slowly growing international, interregional integration process and the increased level of education, the population is generally more open-minded than they used to be a hundred years ago. But as history has shown, no regional, national or international entity should exert negative influence of the population's fears and level of acceptance by moving too fast. The latter may bring about the emergence of extremist parties, old habits and opinions, which threatens any stability and progress. 
Dirk-Hinnerk Fischer holds a master's degree in international economics and business administration from the University of Innsbruck, Austria. He has studied one year at the University of Zaragoza, Spain. As a German citizen he has participated in several projects of international cooperation and exchange. During and after his graduate studies Fischer worked as a consultant for start-up companies from various countries. He is currently a PhD student at TSEBA, the Tallinn University of Technology. In his PhD thesis he focuses on inter-dependencies between competitive European markets and the institutions of the European Union.

\section{Bibliography}

Achrainer, M. \& Hofinger, N. (1999), 'Politik nach Tiroler Art. Ein Dreiklang aus Fleiß, Tüchtigkeit und Zukunftsglaube,' in H. Dachs (ed.) Geschichte der österreichischen Bundesländer seit 1945, Wien: Wien Böhlau.

Alexander, H. (2013), Innovatives Tirol 2007: Techniker, Erfinder, Unternehmer, Österreichisches Patentamt: Marke national, Innsbruck: Medien- \& Verlagsbüro, Europahaus.

Amt der Landesregierung Tirol (2009), Statistisches Handbuch Bundesland Tirol, Innsbruck: Amt der Landesregierung Tirol, pp. 148, 264. Retrieved from https:/www.tirol.gv.at/fileadmin/themen/statistik-budget/statistik/downloads/ Statistisches_Handbuch_2009_Kapitel_1_12.pdf [accessed 5 Dec 2013]

Amt der Tiroler Landesregierung (1948), Die Bevölkerung Tirols 1910 bis 1948, Innsbruck: Amt der Tiroler Landesregierung.

Arbeiterkammer für Tirol (1958), 30 Jahre Arbeitsmarkt in Tirol 1928-1958, Innsbruck: Arbeiterkammer für Tirol.

Bezirksblätter (2012), 'Jedes fünfte Kind hat bereits Übergewicht,' Innsbruck meinbezirk.at, 14 June 2012. Retrieved from http://www.meinbezirk.at/innsbruck/ chronik/jedes-fuenfte-kind-hat-bereits-uebergewicht-d193550.html [accessed 14 Dec 2013]

BHW (1950), Österreichs Kraftfahrzeugbestand 1945-1950, Wien: Bundesministerium für Handel und Wiederaufbau.

BMI (2013), Wahlergebnisse, Nationalratswahl 2013. Retrieved from http://wahl13. bmi.gv.at/ [accessed 10 Dec 2013]

BMVIT (2011), 'Infrastruktur,' in Verkehr in Zahlen 2011, Wien: Bundesministerium für Verkehr, Innovation und Technologie.

Bundespressedienst (1947), Österreichisches Jahrbuch 1945-1946, Wien: Bundespressedienst.

Bureau der K.K... (1915), Ergebnisse der Volkszählung vom 31 Dezember 1910, Bureau der K.K. statistischen Zentralkommission. 
City Population (2013), Tirol (Österreich): Bezirke, Städte und Gemeinden; Einwohnerzahlen \& Karten. Retrieved from http://www.citypopulation.de/php/ austria-tirol_d.php [accessed 3 Dec 2013]

Der Standart (2012), “Heimatliebe statt Marrokkaner-Diebe": Diversion statt Verhetzungsprozess, Der Standart, 4 October 2012. Retrieved from http:// derstandard.at/1348284996206/Heimatliebe-statt-Marokkaner-Diebe-Diversionstatt-Verhetzungsprozess [accessed 12 Dec 2013]

Dokumente... (1908), Dokumente der Leopold-Franzens-Universität zu Innsbruck Studienjahr 1908/1909, Innsbruck: Universität Innsbruck.

Durchschnittsalter der Bevölkerung (2010), Österreich Statistiken 2013. Retrieved from http://de.statista.com/statistik/daten/studie/217730/umfrage/durchschnittsalterder-bevoelkerung-in-oesterreich/ [accessed 12 Nov 2013]

DVT (2013), 'Daten-Verarbeitung-Tirol GmbH: Land Tirol - Wahlen,' Landtagswahl 2008. Retrieved from http://wahlen.tirol.gv.at/landtagswahl_2008/index.html [accessed 15 Nov 2013]

Eisterer, K. (1998), La présence francaise en Autriche (1945-1946): Der französischen Zone mit der Schweiz 1998, Rouen: Publ. de l'Univ. de Rouen Centre d'études et de recherches autrichiennes, vol. 2, Annexe 5.

Fontana, J.; Haider, P.; Leitner, W.; Mühlberger, G.; Palme, R.; Partli, O. \& Riedmann, J., eds. (1987), Geschichte des Landes Tirol! Band 3: Die Zeit von 1848 bis 1918, Bozen: Verlagsanstalt Athesia.

Günther, A. (1951), Tiroler Wirtschaft in Vergangenheit und Gegenwart Band III. Schlernschriften, Innsbruck: Wagner Innsbruck, no. 79(51).

Kernmayr, H. G. (1952), Brot und Eisen. Wanderung durch das Werktätige Tirol, Salzburg: Sirius, pp. 39, 240.

K.K. Statistische Zentral-Kommission (1911), Vorläufige Ergebnisse der Volkszählung vom 31. Dezember 1910 in den im Reichsrate vertretenen Königreichen und Ländern.

Kölner, O. \& Rohn, H. (1910), Denkschrift zur Feier des 20 jährigen Bestandes des Landesverbandes für Fremdenverkehr in Tirol, Innsbruck: Lampe.

Landesstatistik Tirol (2011), Landesstatistik Tirol: Daten 2011. Retrieved from https:// www.tirol.gv.at/fileadmin/themen/statistik-budget/statistik/downloads/stat fold11.pdf [accessed 7 Dec 2013]

— (2013), Landesstatistik Tirol: Tirol Daten 2013. Retrieved from https://www.tirol. gv.at/fileadmin/themen/statistik-budget/statistik/stat-fold13.pdf [accessed 7 Dec 2013]

Nussbaumer, J. (1985), 'Zur sozialen und wirtschaftlichen Lage Nordtirols im Jahre 1945,' in Tiroler Heimat. Jahrbuch für Geschichte und Volkskunde 1984, 1984/1985, Innsbruck: Universitätsverlag Wagner.

Nussbaumer, J. \& Neuner, S. (2012), Die Graphen von Tirol. Ein Bilderbuch für Neugierige, Innsbruck: Studia Universitätsverlag Innsbruck. 
Österreichische Gesellschaft Statistiches Handbuch 1913 (1914), Wien: Österreichische Gesellschaft für historisches Kraftfahrwesen.

Österreichisches Patentblatt (1953), Herausgegeben vom K.K. Patentamt, 1909-1914; 1947-1952.

Österreichisches statistisches Zentralamt (1951), Vorläufige Hauptergebnisse der Volkszählung vom 1. Juni 1951 nach Gemeinden, Wien: Österreichisches Statistisches Zentralamt, pp. 95ff.

Österreichischer Zentralkataster (1908), Österreichischer Zentralkataster sämtlicher Handels-, Industrie- und Gewerbebetriebe 1908, Die hohen K.K. Ministerien des Inneren und des Handels, vol. IX.

Rauchenberger, J. \& Fasching, G. eds. (2000), Stichwort Bundesländer. Bundesrat. Wahlen und Vertretungskörper der Länder von 1945 bis 2000, Wien: PR-Verl.

Statistisches Handbuch 1912 (1913), K.K. Statistische Zentral-Kommission.

Statistisches Handbuch Österreich 1950 (1950), Wien: Österreichisches statistisches Zentralamt, p. 223.

Statistische Übersicht... (2011), Statistische Übersicht über Geschäftsumfang und Geschäftstätigkeit des österreichischen Patentamtes. Retrieved from http://www. patentamt.at/Media/2007.pdf [accessed 11 Dec 2013]

Statistik Austria (2013a), 'Bevölkerung nach dem Religionsbekenntnis und Bundesländern 1951 bis 2001,' Statistik Austria, Wien: Bundesanstalt Statistik Österreich.

(2013b), 'Lebenserwartung für ausgewählte Altersjahre 1868/71 bis 2010/12, 1951 bis 2012,' Statistik Austria. Retrieved from http://www.statistik.at/web_de/ services/publikationen/2/index.html?listid=2\&detail=609 [accessed 9 Dec 2013]

— (2013c), 'Scheidungen,' Statistik Austria. Retrieved from http://www.statistik. at/web_de/statistiken/bevoelkerung/scheidungen/022912.html [accessed 14 Dec 2013]

— (2013d), 'Sterbefälle,' Statistik Austria. Retrieved from http://www.statistik.at/ web_de/statistiken/bevoelkerung/sterbefaelle/024811.html [accessed 10 Dec 2013]

(2013e), 'Wohnungswesen 2013,' Statistik Austria: Statistisches Jahrbuch Österreich 2013. Wien: Bundesanstalt Statistik Österreich.

Stolz, O. (1955), Geschichte des Landes Tirol, Innsbruck: Tyrolia-Verlag.

'Tirol Geschichte' (2013), Skizze Tirol nach 1918. Retrieved from http://tirol-geschichte. tsn.at/fotos/geschichte/erster-weltkrieg/skizze-tirol-nach-1918-klein-01.jpg [accessed 14 Sep 2014]

Tiroler Tageszeitung (2013), 'Problem Analphabetismus: 775 Millionen sind betroffen,' Retrieved from http://www.tt.com/panorama/gesellschaft/7107670-91/problemanalphabetismus-775-millionen-sind-betroffen.csp [accessed 12 Dec 2013] 